\title{
USULAN PERBAIKAN KUALITAS PRODUK MASKER DENGAN MENGGUNAKAN METODE SIX SIGMA DI ARALUZE KONVEKSI BANDUNG
}

\author{
Jessica Marcelline Mesinay ${ }^{1}$, Rifqi Arief Adrianto ${ }^{2}$, Reina Syahfina ${ }^{3}$ \\ Fakultas Teknik ${ }^{1,2,3}$ \\ Universitas Widyatama \\ Jl. Cikutra No. 204 A Bandung \\ jessica.marcelline@widyatama.ac.id ${ }^{1}$ rifqi.arief@widyatama.ac.id ${ }^{2}$ reina.syahfina@widyatama.ac.id ${ }^{3}$
}

\begin{abstract}
Abstrak
Pandemi Corona Virus Disease-19 di Indonesia berkembang sangat pesat dan bertransmisi melalui droplet yang keluar dari mulut dan hidung. Maka, World Health Oganization (WHO) menyarankan pemakaian masker untuk menekan angka penularan virus ini. Kebutuhan masker tentu meningkat sehingga banyak pelaku usaha seperti konveksi yang memproduksi masker dengan jumlah banyak. Penelitian ini bertujuan untuk mengetahui kualitas masker kain dengan mengidentifikasi kecacatan yang terjadi pada produk, akar permasalahan, serta solusi yang diberikan di Araluze Konveksi. Data yang digunakan adalah data sekunder berupa data kecacatan produk selama 30 hari yang diperoleh dari Araluze Konveksi. Penelitian ini dianalisis dengan menggunakan peta kendali, diagram pareto, diagram fishbone, dan perhitungan nilai DPMO. Diperoleh nilai sigma sebesar 3,39\% dengan jenis cacat tertinggi yaitu jahitan tidak rapi. Setelah mengetahui penyebab kecacatan, maka diberikan usulan perbaikan untuk mengurangi kecacatan hingga nol (zero defect).
\end{abstract}

Kata kunci : Six Sigma, Zero Defect, Kualitas

\begin{abstract}
The Corona Virus Disease-19 pandemic in Indonesia is growing very rapidly and transmitting through droplets that come out of the mouth and nose. The World Health Organization (WHO) recommends the use of masks to reduce the transmission rate of the virus. Requirement for masks has certainly increased so that many business actors, such as convection, are producing masks in large quantities. This study aims to determine the quality of cloth masks by identifying the defects that occur in the product, the root of the
\end{abstract}

problem, and the solutions given in Araluze Konveksi. The data used are secondary data in the form of product defect data for 30 days obtained from Araluze Konveksi. This study was analyzed using a control chart, pareto diagram, fishbone diagram, and calculation of the DPMO value. Obtained a sigma value of $3.39 \%$ with the highest type of defect that is untidy stitches. After knowing the cause of the defect, a recommendation is given to reduce the zero defect.

Keywords : Six Sigma, Zero Defect, Quality

\section{Pendahuluan}

Pandemi Corona Virus Disease-19 di Indonesia berkembang sangat pesat. Menurut data yang diperoleh dari website resmi penanganan Covid-19 di Indonesia angka kematian akibat kasus ini mencapai kurang lebih dua puluh ribu orang. Virus ini sangat cepat menyebar terutama melalui droplet. Droplet merupakan media transmisi melalui hidung dan mulut. World Health Oganization (WHO) menyarankan beberapa langkah untuk memutuskan rantai penyebaran virus ini salah satunya adalah memakai masker.

Penggunaan masker merupakan salah satu cara termudah untuk semua orang dapat melakukan kegiatan preventif atau upaya pencegahan penyebaran droplet. Kebutuhan masker tentu meningkat semenjak pandemi ini sehingga banyak pelaku usaha seperti konveksi yang memproduksi masker dengan jumlah banyak. Araluze Konveksi yang berlokasi di daerah Kopo Bandung ini memproduksi masker kain dengan berbagai macam bentuk. Namun, dalam menjalankan proses produksinya Araluze Konveksi masih saja menemukan kendala yaitu salah satunya cacat produk. 
Pada proses produksi, salah satu tujuan utama suatu perusahaan adalah memproduksi dengan tidak adanya cacat produk atau zero defect. Apabila potensi cacat ditemukan, maka harus ada tindakan preventif untuk memperbaiki kualitas produk. Kualitas produk memberikan identitas pada setiap perusahaan dan kriteria penting yang dipertimbangkan konsumen dalam pemilihan produk. Menurut Kotler dan Amstrong (2008) kualitas produk adalah senjata strategi yang berpotensi untuk mengalahkan pesaing. Oleh karena itu, Araluze Konveksi perlu melakukan pengendalian kualitas dan perbaikan. Pengendalian kualitas dilakukan dengan menggunakan metode Six Sigma. Metode ini dibutuhkan untuk mengetahui seberapa besar nilai sigma yang telah dicapai, serta mengidentifikasi faktor penyebab kecacatan dan perbaikan yang sebaiknya diterapkan di Araluze Konveksi.

\section{KAJIAN LITERATUR}

\section{Kualitas}

Menurut Heizer dan Render (2009) menyebutkan bahwa kualitas adalah seluruh karakteristik produk baik barang maupun jasa yang mampu memenuhi kebutuhan. Heizer dan Render kemudian mengemukakan tiga alasan pentingnya kualitas bagi suatu perusahaan yaitu kualitas memengaruhi jati diri sebuah perusahaan, kualitas dapat meningkatkan loyalitas konsumen, dan kualitas bersaing dalam keterlibatan global.

\section{Pengendalian Kualitas}

Pengendalian kualitas berarti usaha untuk mempertahankan kualitas barang yang dihasilkan agar sesuai dengan karakteristik atau standar yang telah ditetapkan seperti yang disampaikan oleh Sofjan Assauri (2008). Tujuan dari pengendalian kualitas adalah agar barang yang diproduksi dapat mencapai sebuah standar yang ditetapkan dan menekan biaya operasional sekecil mungkin. Secara umum dibagi menjadi dua yaitu pengendalian selama proses produksi dan pengendalian setelah barang selesai diproduksi.

\section{Lean Six Sigma}

Gaspersz (2007) mengemukakan Lean Six Sigma sebagai sebuah pendekatan yang bertujuan untuk mengurangi faktor penyebab cacat produk, menghilangkan pemborosan, dan meningkatkan nilai tambah produk atau jasa. Terdapat enam kunci yang perlu diperhatikan dalam metode ini diantaranya mengidentifikasi pelanggan, mengidentifikasi produk, mengidentifikasi kebutuhan, mendefinisikan proses, menghindari kesalahan dan pemborosan, serta meningkatkan proses secara terus menerus dan berkesinambungan.

\section{Zero Defect}

Halpin et al (1966) mendefinisikan zero defect sebagai instrumen manajemen yang digunakan untuk mengurangi kecacatan sebagai langkah preventif. Konsep dari zero defect itu sendiri adalah memastikan semua cacat hilang pada proses yang ada di langkah pertama. Zero defect dapat menjadi acuan untuk meningkatkan kualitas dan dapat memenuhi keinginan pelanggan.

\section{Diagram Pareto}

Diagram Pareto merupakan metode untuk mengelola data kecacatan atau kesalahan masalah produk untuk membantu memusatkan perhatian serta mencari sebuah solusi penyelesaian masalah seperti yang disampaikan oleh Heizer dan Rander (2015).

\section{Diagram Fishbone}

Diagram Fishbone dikenalkan pertama kali oleh Ishikawa pada tahun 1968. Diagram ini menunjukkan hubungan sebab-akibat dari sebuah permasalahan. Metode ini digunakan untuk mencari akar permasalahan (root causes) atau variabel beragam yang berpotensi menyebabkan defect.

\section{Peta Kendali}

Peta kendali merupakan metode pengendalian kualitas statistik. Peta ini merupakan data yang disajikan dalam bentuk grafik dan digunakan untuk menilai pengendalian kualitas sebuah sistem produksi. Peta kendali ini menentukan control limit, upper control limit, dan lower control limit. Peta kendali yang digunakan dalam penelitian adalah peta kendali P. Sample yang digunakan sebanyak 30 buah.

\section{ANALISIS DAN PEMbahasan}

\section{Teknik Pengumpulan Data}

Pengumpulan data dalam penelitian ini dilakukan dengan observasi yaitu pengamatan langsung di Araluze Konveksi dan melakukan wawancara dengan informan yaitu pemilik konveksi dan para pekerja. Data sekunder diperoleh dari data kecacatan yang diperoleh dari data internal perusahaan. 
Beberapa tahapan dalam Metode Six Sigma diantaranya sebagai berikut:

\subsection{Define}

Tahapan define mendefinisikan seberapa proporsi kecacatan yang menjadi penyebab dalam kegagalan produksi. Pada produksi masker di Araluze Konveksi didapatkan tiga jenis cacat yang sebenarnya didefinisikan sebagai Critical to Quality (CTQ). Keterangan untuk tiga jenis cacat dapat dilihat pada Tabel 1 dibawah ini:

Tabel 1. Critical to Quality (CTQ)

\begin{tabular}{|c|c|}
\hline Jenis Cacat & Keterangan \\
\hline Cacat Bahan (A) & Bahan terlalu tipis, bahan terlalu kaku \\
\hline Ukuran Tidak Sesuai (B) & $\begin{array}{c}\text { Ukuran masker tidak sesuai dengan strandar } \\
\text { ukuran yang telah ditentukan }\end{array}$ \\
\hline Jahitan Tidak Rapi (C) & Benang bertumpuk, jahitan tidak lurus \\
\hline
\end{tabular}

Critical to Quality sebenarnya merupakan terjemahan dari voice of customer. Sebuah produk tentu harus mencapai sebuah standar dari spesifikasi untuk memuaskan kebutuhan pelanggan. Setelah mengidentifikasi jenis-jenis cacat, maka dilakukan pengambilan data untuk mengetahui jumlah dan persentase kecacatan produk selama 30 hari seperti yang dilihat pada Tabel 2 dibawah ini:

Tabel 2. Persentase Jenis Cacat

\begin{tabular}{|c|c|c|c|c|c|}
\hline \multirow{2}{*}{ Hari } & \multirow{2}{*}{$\begin{array}{c}\text { Jumlah } \\
\text { Produksi }\end{array}$} & \multicolumn{3}{|c|}{ Jenis Cacat } & \multirow{2}{*}{$\begin{array}{r}\text { Jumlah } \\
\text { Cacat }\end{array}$} \\
\hline & & A & B & C & \\
\hline 1 & 182 & 11 & 8 & 3 & 22 \\
\hline 2 & 100 & 6 & 12 & 7 & 25 \\
\hline 3 & 214 & 8 & 9 & 9 & 26 \\
\hline 4 & 297 & 11 & 7 & 8 & 26 \\
\hline 5 & 247 & 10 & 7 & 3 & 20 \\
\hline 6 & 270 & 9 & 7 & 3 & 19 \\
\hline 7 & 196 & 6 & 7 & 7 & 20 \\
\hline 8 & 113 & 5 & 11 & 3 & 19 \\
\hline 9 & 260 & 9 & 6 & 5 & 20 \\
\hline 10 & 296 & 10 & 5 & 8 & 23 \\
\hline 11 & 289 & 12 & 9 & 4 & 25 \\
\hline 12 & 284 & 6 & 5 & 2 & 13 \\
\hline 13 & 147 & 5 & 8 & 4 & 17 \\
\hline 14 & 236 & 13 & 5 & 4 & 22 \\
\hline 15 & 223 & 14 & 7 & 8 & 29 \\
\hline 16 & 249 & 14 & 5 & 3 & 22 \\
\hline 17 & 290 & 8 & 12 & 8 & 28 \\
\hline 18 & 114 & 10 & 7 & 5 & 22 \\
\hline 19 & 166 & 11 & 11 & 3 & 25 \\
\hline 20 & 222 & 9 & 12 & 3 & 24 \\
\hline 21 & 153 & 7 & 9 & 8 & 24 \\
\hline 22 & 142 & 9 & 12 & 4 & 25 \\
\hline 23 & 207 & 5 & 7 & 6 & 18 \\
\hline 24 & 248 & 5 & 8 & 8 & 21 \\
\hline 25 & 157 & 9 & 11 & 7 & 27 \\
\hline 26 & 238 & 13 & 6 & 5 & 24 \\
\hline 27 & 200 & 15 & 9 & 6 & 30 \\
\hline 28 & 164 & 14 & 12 & 7 & 33 \\
\hline 29 & 178 & 13 & 8 & 4 & 25 \\
\hline 30 & 108 & 6 & 5 & 10 & 21 \\
\hline Total & 6190 & 283 & 247 & 165 & 695 \\
\hline
\end{tabular}

(Sumber: Araluze Konveksi)

\subsection{Measure}

Tahapan measure didefinisikan sebagai salah satu langkah pengukuran permasalahan. Pada tahap ini dilakukan pembuatan peta kendali untuk menentukan apakah hasil kerja suatu proses masih dapat dipertahankan pada taraf kualitas yang dapat diterima. Sebelum membuat peta kendali, terlebih dahulu adalah menghitung persentase cacat, contol limit, upper control limit, dan low control limit seperti yang disajikan pada Tabel 3 dibawah ini:

\section{Tabel 3. Perhitungan Batas Kontrol}

\begin{tabular}{|c|c|c|c|c|c|c|}
\hline Hari & $\begin{array}{c}\text { Jumlah } \\
\text { Produksi }\end{array}$ & $\begin{array}{c}\text { Jumlah } \\
\text { Cacat }\end{array}$ & $\begin{array}{c}\text { Persentase } \\
\text { Cacat (P) }\end{array}$ & LCL & CL & UCL \\
\hline 1 & 182 & 22 & 0,1209 & $-0,1665$ & 0,1123 & 0,1794 \\
\hline 2 & 100 & 25 & 0,2500 & $-0,1665$ & 0,1123 & 0,1794 \\
\hline 3 & 214 & 26 & 0,1215 & $-0,1665$ & 0,1123 & 0,1794 \\
\hline 4 & 297 & 26 & 0,0875 & $-0,1665$ & 0,1123 & 0,1794 \\
\hline 5 & 247 & 20 & 0,0810 & $-0,1665$ & 0,1123 & 0,1794 \\
\hline 6 & 270 & 19 & 0,0704 & $-0,1665$ & 0,1123 & 0,1794 \\
\hline 7 & 196 & 20 & 0,1020 & $-0,1665$ & 0,1123 & 0,1794 \\
\hline 8 & 113 & 19 & 0,1681 & $-0,1665$ & 0,1123 & 0,1794 \\
\hline 9 & 260 & 20 & 0,0769 & $-0,1665$ & 0,1123 & 0,1794 \\
\hline 10 & 296 & 23 & 0,0777 & $-0,1665$ & 0,1123 & 0,1794 \\
\hline 11 & 289 & 25 & 0,0865 & $-0,1665$ & 0,1123 & 0,1794 \\
\hline 12 & 284 & 13 & 0,0458 & $-0,1665$ & 0,1123 & 0,1794 \\
\hline 13 & 147 & 17 & 0,1156 & $-0,1665$ & 0,1123 & 0,1794 \\
\hline 14 & 236 & 22 & 0,0932 & $-0,1665$ & 0,1123 & 0,1794 \\
\hline 15 & 223 & 29 & 0,1300 & $-0,1665$ & 0,1123 & 0,1794 \\
\hline 16 & 249 & 22 & 0,0884 & $-0,1665$ & 0,1123 & 0,1794 \\
\hline 17 & 290 & 28 & 0,0966 & $-0,1665$ & 0,1123 & 0,1794 \\
\hline 18 & 114 & 22 & 0,1930 & $-0,1665$ & 0,1123 & 0,1794 \\
\hline 19 & 166 & 25 & 0,1506 & $-0,1665$ & 0,1123 & 0,1794 \\
\hline 20 & 222 & 24 & 0,1081 & $-0,1665$ & 0,1123 & 0,1794 \\
\hline 21 & 153 & 24 & 0,1569 & $-0,1665$ & 0,1123 & 0,1794 \\
\hline 22 & 142 & 25 & 0,1761 & $-0,1665$ & 0,1123 & 0,1794 \\
\hline 23 & 207 & 18 & 0,0870 & $-0,1665$ & 0,1123 & 0,1794 \\
\hline 24 & 248 & 21 & 0,0847 & $-0,1665$ & 0,1123 & 0,1794 \\
\hline 25 & 157 & 27 & 0,1720 & $-0,1665$ & 0,1123 & 0,1794 \\
\hline 26 & 238 & 24 & 0,1008 & $-0,1665$ & 0,1123 & 0,1794 \\
\hline 27 & 200 & 30 & 0,1500 & $-0,1665$ & 0,1123 & 0,1794 \\
\hline 28 & 164 & 33 & 0,2012 & $-0,1665$ & 0,1123 & 0,1794 \\
\hline 29 & 178 & 25 & 0,1404 & $-0,1665$ & 0,1123 & 0,1794 \\
\hline 30 & 108 & 21 & 0,1944 & $-0,1665$ & 0,1123 & 0,1794 \\
\hline Total & 6190 & 695 & & & & \\
\hline $1 S 4 m b e r: P e n g$ & & & & \\
\hline
\end{tabular}

(Sumber: Pengolahan Data)

Berdasarkan hasil pengolahan data diatas, didapatkan nilai probabilitas cacat terbesar di hari ke2 yaitu sebesar 0,2500 dan probabilitas cacat terkecil pada hari ke-12 yaitu sebesar 0,0458. Diperoleh hasil 0,1123 untuk control limit, upper control limit sebesar 0,1794 dan low control limit sebesar -0,1665 dan selanjutnya dibuat peta kendali yang dapat dilihat pada Gambar 1 dibawah ini:

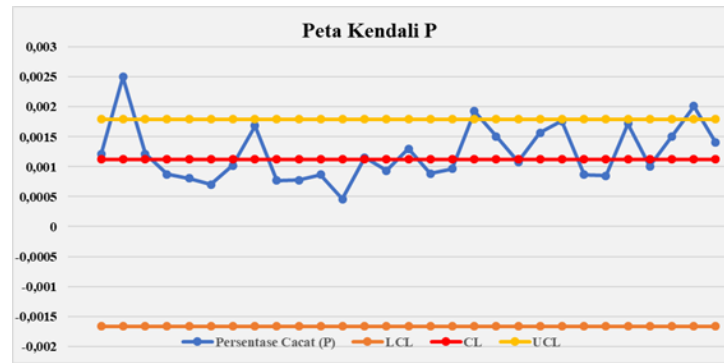

Gambar 1. Peta Kendali Produk Cacat (Sumber: Pengolahan Data)

Jessica Marcelline Mesinay, Rifqi Arief Adrianto, Reina Syahfina 
Pada gambar diatas terlihat bahwa 30 sampel yang diambil tidak sepenuhnya masuk kedalam batas kendali. Namun, sebaran garis masih fluktuatif sehingga Araluze Konveksi membutuhkan perbaikan untuk menurunkan cacat hingga nol persen atau zero defect.

Selanjutnya dilakukan perhitungan untuk mengetahui nilai Defect per Million Opportunities (DPMO) dan Sigma yang merupakan kapabilitas dalam sebuah proses produksi. Berikut merupakan tabel hasil perhitungan DPMO dan Sigma:

Tabel 4. Perhitungan DPMO dan Sigma

\begin{tabular}{|c|c|c|c|c|c|}
\hline Hari & \begin{tabular}{|c|} 
Jumlah \\
Produksi
\end{tabular} & $\begin{array}{c}\text { Jumlah } \\
\text { Cacat }\end{array}$ & $\begin{array}{c}\begin{array}{c}\text { Probabilitas } \\
\text { Cacat }\end{array} \\
\end{array}$ & DPMO & Nilai Sigma \\
\hline 1 & 182 & 22 & 0,1209 & 30220 & 3,38 \\
\hline 2 & 100 & 25 & 0,2500 & 62500 & 3,03 \\
\hline 3 & 214 & 26 & 0,1215 & 30374 & 3,38 \\
\hline 4 & 297 & 26 & 0,0875 & 21886 & 3,52 \\
\hline 5 & 247 & 20 & 0,0810 & 20243 & 3,55 \\
\hline 6 & 270 & 19 & 0,0704 & 17593 & 3,61 \\
\hline 7 & 196 & 20 & 0,1020 & 25510 & 3,45 \\
\hline 8 & 113 & 19 & 0,1681 & 42035 & 3,23 \\
\hline 9 & 260 & 20 & 0,0769 & 19231 & 3,57 \\
\hline 10 & 296 & 23 & 0,0777 & 19426 & 3,57 \\
\hline 11 & 289 & 25 & 0,0865 & 21626 & 3,52 \\
\hline 12 & 284 & 13 & 0,0458 & 11444 & 3,78 \\
\hline 13 & 147 & 17 & 0,1156 & 28912 & 3,40 \\
\hline 14 & 236 & 22 & 0,0932 & 23305 & 3,49 \\
\hline 15 & 223 & 29 & 0,1300 & 32511 & 3,35 \\
\hline 16 & 249 & 22 & 0,0884 & 22088 & 3,51 \\
\hline 17 & 290 & 28 & 0,0966 & 24138 & 3,47 \\
\hline 18 & 114 & 22 & 0,1930 & 48246 & 3,16 \\
\hline 19 & 166 & 25 & 0,1506 & 37651 & 3,28 \\
\hline 20 & 222 & 24 & 0,1081 & 27027 & 3,43 \\
\hline 21 & 153 & 24 & 0,1569 & 39216 & 3,26 \\
\hline 22 & 142 & 25 & 0,1761 & 44014 & 3,21 \\
\hline 23 & 207 & 18 & 0,0870 & 21739 & 3,52 \\
\hline 24 & 248 & 21 & 0,0847 & 21169 & 3,53 \\
\hline 25 & 157 & 27 & 0,1720 & 42994 & 3,22 \\
\hline 26 & 238 & 24 & 0,1008 & 25210 & 3,46 \\
\hline 27 & 200 & 30 & 0,1500 & 37500 & 3,28 \\
\hline 28 & 164 & 33 & 0,2012 & 50305 & 3,14 \\
\hline 29 & 178 & 25 & 0,1404 & 35112 & 3,31 \\
\hline 30 & 108 & 21 & 0,1944 & 48611 & 3,16 \\
\hline Total & 6190 & 695 & 3,7273 & & \\
\hline Rata-rata & 206 & 23 & 0,1242 & 31061 & 3,39 \\
\hline
\end{tabular}

(Sumber: Pengolahan Data)

Berdasarkan data yang disajikan pada tabel diatas, Araluze Konveksi mempunyai rata-rata produksi 206 masker dengan rata-rata cacat sebanyak 23 masker per hari dan memiliki probabilitas sebesar 0,1242 . Diperoleh angka DPMO sebesar 31061 yang berarti setiap satu juta unit diproduksi, didapatkan kecacatan sebanyak 31061. Nilai Sigma diperoleh hasil sebesar 3,39 yang berarti setiap proses produksi tidak akan terdapat cacat melebihi 3,39\% akan tetapi Araluize Konveksi tetap harus melakukan perbaikan agar kecacatan dapat diminimalisir.

\subsection{Analyze}

Pada tahap analyze dilakukan analisis dan validasi terhadap akar permasalahan (root causes) dan mencari solusi melalui pertanyaan atau hipotesis. Pada Araluze Konveksi dilakukan analisis berdasarkan data yang diperoleh dan kemudian diubah ke dalam Diagram Pareto seperti berikut:

Tabel 5. Akumulasi Cacat Produk

\begin{tabular}{|c|c|c|c|}
\hline Jenis Cacat & Frekue nsi & Pers entase & A kumulasi \\
\hline Cacat Bahan (A) & 165 & $23,74 \%$ & $23,74 \%$ \\
\hline Ukuran Tidak Sesuai (B) & 247 & $35,54 \%$ & $59,28 \%$ \\
\hline Jahitan Tidak Rapi (C) & 283 & $40,72 \%$ & $100,00 \%$ \\
\hline
\end{tabular}

(Sumber: Pengolahan Data)

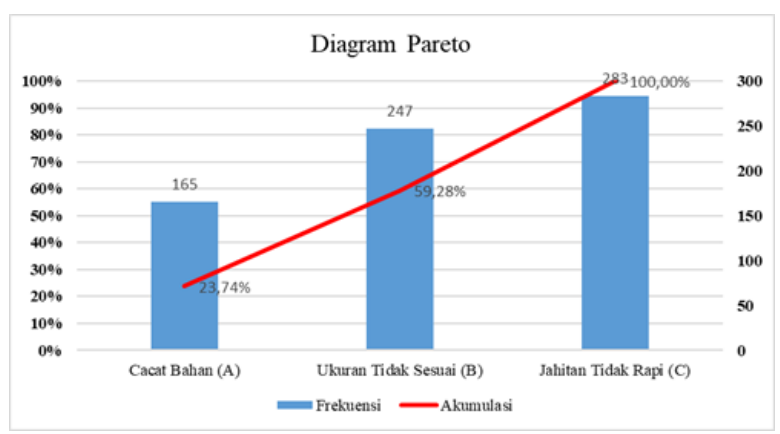

Gambar 2. Diagram Pareto

(Sumber: Pengolahan Data)

Dari diagram yang disajikan diatas, diketahui bahwa jenis cacat jahitan tidak rapi merupakan cacat tertinggi yaitu sebesar $40,72 \%$ lalu kedua adalah ukuran yang tidak sesuai dengan standar dan cacat bahan. Dengan hasil demikian, maka akar permasalahan pada proses produksi masker yaitu jahitan tidak rapi. Selanjutnya identifikasi penyebab dari jenis cacat jahitan tidak rapi menggunakan diagram fishbone seperti gambar yang disajikan dibawah ini:

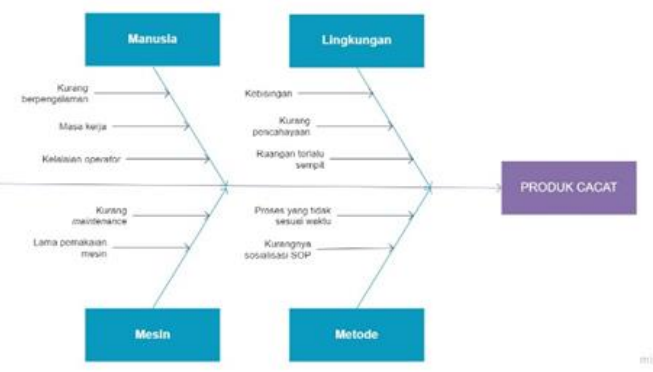

Gambar 3. Diagram Fishbone

(Sumber: Pengolahan Data)

Jessica Marcelline Mesinay, Rifqi Arief Adrianto, Reina Syahfina 


\subsection{Improve}

Setelah mendapatkan akar permasalahan serta solusi, pada tahap improve ini dilakukan tindakan perbaikan. Berikut dibawah ini beberapa perbaikan yang dapat diterapkan pada Araluze Konveksi:

Tabel 6. Usulan Perbaikan

\begin{tabular}{|c|c|c|}
\hline No. & Penye bab Cacat & Rekomendas i Perbaikan \\
\hline 1 & Kurang berpengalaman & \multirow{3}{*}{$\begin{array}{c}\text { Mengadakan kegiatan pelatihan terutama } \\
\text { kepada pekerja yang masa kerjanya dibawah } 1 \\
\text { tahun }\end{array}$} \\
\hline 2 & Masa kerja & \\
\hline 3 & Kelalaian operator & \\
\hline 4 & Kebisingan & \multirow{3}{*}{$\begin{array}{l}\text { Menga tur layout stasiun kerja, menetapkan } \\
\text { standar pencahayaan }\end{array}$} \\
\hline 5 & Kurang pencahayaan & \\
\hline 6 & Ruangan terlalu sempit & \\
\hline 7 & Kurang maintenance & \multirow{2}{*}{$\begin{array}{c}\text { Melakukan penjadwalan pemeliharaan secara } \\
\text { berkala }\end{array}$} \\
\hline 8 & Lama pemakaian mesin & \\
\hline 9 & Proses yang tidak sesuai waktu & \multirow{2}{*}{$\begin{array}{c}\text { Melakukan evalua si kerja dan penyesuaian SOP } \\
\text { dengan rutin }\end{array}$} \\
\hline 10 & Kurangnya sosialisasi SOP & \\
\hline
\end{tabular}

(Sumber: Pengolahan Data)

\subsection{Control}

Tahap terakhir adalah melakukan kontrol terhadap rekomendasi perbaikan yang telah diberikan. Kontrol dilakukan untuk melihat pengaruh sebelum dan sesudah penerapan six sigma dalam pengendalian kualitas produk masker di Araluze Konveksi.

\section{KESIMPULAN DAN SARAN}

Berdasarkan pembahasan diatas maka dapat disimpulkan beberapa hal diantaranya adalah sebagai berikut: (1) Kualitas produk masker di Araluze Konveksi tergolong baik. (2) Terdapat tiga jenis cacat pada produk masker dan cacat tertinggi pada jahitan tidak rapi. (3) Terdapat beberapa solusi untuk rekomendasi perbaikan masalah setelah dianalisis menggunakan diagram fishbone. Diagram fishbone menguraikan akar permasalahan dari aspek manusia, mesin, metode, dan lingkungan.

Saran yang dapat diberikan adalah setiap jenis cacat sebaiknya dipisahkan. Hal ini untuk memudahkan kecacatan disortir agar mudah diperbaiki nantinya. Untuk kedepannya perlu adanya pelatihan terhadap tenaga kerja agar terampil dalam setiap prosesnya, perlu adanya evaluasi terhadap standard operating procedure, mengatur layout stasiun kerja, dan melakukan pemeliharaan mesin.

\section{REFERENSI}

Assauri, Sofjan. (2016). Manajemen Operasi Produksi. Jakarta: PT Raja Grafindo Persada.

Gaspersz, Vincent. (2007). Lean Six Sigma for Manufacturing and Services Industries. Jakarta: PT Gramedia Pustaka Utama.

Heizer, Jay \& Barry Rander. (2015). Manajemen Operasi: Manajemen

Zulian, Yamit. (2013). Manajemen Kualitas Produk \& Jasa. Yogyakarta: Ekonisia. 